American Journal of Microbiology 1 (2): 30-35, 2010

ISSN 1948-982x

(C) 2010 Science Publications

\title{
Isolation of Amylolytic Bacteria from Viscera of Labeo rohita (Ham.) and Optimization of Alpha Amylase Extraction
}

\author{
${ }^{1}$ Debabrat Baishya and ${ }^{2}$ Hridip Kumar Sarma \\ ${ }^{1}$ Department of Biotechnology and Bioengineering, Institute of Science and Technology, \\ Gauhati University, Guwahati-781014, Assam, India \\ ${ }^{2}$ Department of Biotechnology, Gauhati University, Guwahati-781014, Assam, India
}

\begin{abstract}
Problem statement: Fish is largely consumed in the north-eastern part of India resulting in the generation of huge amount of fish viscera in the market places. These waste generated is not properly managed for disposal. Under such circumstances it is necessary to properly utilize this waste regenerating the possibility of environment friendly disposal. Besides, industrially and commercially useful biological products like enzymes can be obtained from these sources which, therefore, can benefit the human society through proper exploitation utilizing modern technological innovations. Although there are well established commercially viable protocols for large scale production of $\alpha$ amylase, but it is a known fact that it requires extensive infrastructure including microbial culture laboratory and large scale processes for providing optimum conditions to industrially important microbes for the production of enzymes at an industrial scale. This requires huge expanses in terms of money and time. Approach: In the present investigations, we report the development of optimized parameters for the extraction of $\alpha$-amylase from the viscera of Labeo rohita (Ham.) after isolation and screening of amylolytic bacteria from the viscera of Labeo rohita (Ham.). The potent amylolytic bacterial isolate was subjected to solid substrate fermentation to enhance the production of $\alpha$-amylase. Results: Optimization of different parameters during solid state fermentation enhanced the expression of the enzyme activity from 24.75-60.2 Unit $\mathrm{g}^{-1}$. Out of 15 amylolytic bacterial isolates obtained in the following studies, Bacillus megaterium showed the highest amylolytic activity $\left(11\right.$ Unit $\left.^{-1}\right)$ when wheat bran was used as the carbon substrate during fermentation for 5 days at $37^{\circ} \mathrm{C}$. Conclusion: This report support the proper use of human generated biological wastes for developing low cost technology in producing commercially viable and economically important biological molecules like enzymes for human benefit.
\end{abstract}

Key words: $\alpha$-Amylase, amylolytic bacteria, starch degradation, Bacillus megaterium, indigenous amylases, Labeo rohita, isolating amylases, enzymatic activity, amylolytic activity

\section{INTRODUCTION}

Alpha amylase [EC 3.2.1.1] is an enzyme that hydrolyzes $\alpha$ bonds of large $\alpha$ linked polysaccharides such as starch and glycogen yielding glucose and maltose. $\alpha$-amylase rapidly fragment starch molecule by cleaving the $\alpha-1, \quad 4$-D-glycosidic linkage of carbohydrate polymers more or less at random, thereby bringing about a slow conversion of starch to reducing sugars. Incubation of amylose and dextin with $\alpha$ amylase ultimately yields mainly maltose (Mehrabadi and Bandani, 2009). $\alpha$-amylase requires calcium as cofactor that is bound to the enzyme molecule very tightly and is required for enzymatic activity and conformational stabilization. The presence of appropriate ions could easily increase the activity of enzyme tenfold or more. For industrial use of enzymes, various factors such as specificity, thermostability, activation and inhibition, availability and cost determine the selection of the enzyme from any of the sources (Al-Quadan et al., 2009). There are reports of production of enzymes from bacteria using solid-state fermentation. Most of the extra cellular enzymes can be used at about $60^{\circ} \mathrm{C}$ temperature or even above (Jarrar, 2009). They also have fairly broad tolerance to $\mathrm{pH}$ and long-term storage stability; (Mojentale et al., 2010, Harrison et al., 2009). However, depending upon the sources, the efficiency also differs among different types of amylases (Ling et al., 2009). A good source of amylases is fishes and the species of carps in particular.

Corresponding Author: Debabrat Baishya, Department of Biotechnology and Bioengineering, Institute of Science and Technology, Gauhati University, Guwahati-781 014, Assam, India Tel: +91 9864012267 
The present study aims at isolating amylases from viscera of Labeo rohita (Ham.) which are abundantly consumed by the communities of this region. The fish species is readily available in the local markets and the viscera are not used as a source of food and thus are rejected that lead to a large source of waste generation in commercial places contributing to pollution of water and soil resources. Moreover, very few reports are available that justify the extraction of enzymes directly from waste products without involving any expansive infrastructure and with a low cost approach. This study therefore is an effort to minimize pollution caused due to ignorant generation of such wastes and at the same time utilize them for the benefit of mankind.

\section{MATERIALS AND METHODS}

Sample collection: The viscera of Labeo rohita (Ham.) were taken from the Barabazar, Maligaon, Guwahati, Assam. The experimental results in all the cases were the average of three replicas.

Physicochemical analysis: The $\mathrm{pH}$ of the sample was measured using a $\mathrm{pH}$ meter (Systronics, India) and the titrable acidity was determined in terms of Lactic acid using $1 \mathrm{~N} \mathrm{NaOH}$ solution and phenolphthalein as indicator.

Detection of amylase: Presence of Amylase was detected by starch agar plate assay method. $10 \mathrm{~g}$ viscera were ground in $50 \mathrm{ml}$ distilled water and incubated for $2 \mathrm{~h}$ at room temperature. After incubation it was centrifuged at 4000rpm (REMI 8C, India) for 5 minutes. Then $5 \mathrm{ml}$ of the supernatant was filtered with the help of a membrane filtration system (HIMEDIA SF82) to make it sterile. Further sterile circular discs were dipped into the sterile supernatant for $5 \mathrm{~min}$. and then were placed onto Starch agar plate and incubated at $37^{\circ} \mathrm{C}$ for $24 \mathrm{~h}$. After incubation, the plates were flooded with $70 \%$ Logul's iodine solution.

Effect of extraction time on enzyme: The extraction of enzyme from the collected viscera was done at $2 \mathrm{~h}$ interval, $3 \mathrm{~h}$ after slaughtering and continued until $9 \mathrm{~h}$.

Preparation of crude enzyme extract and optimization of parameters: Different solvents like $10 \%$ methanol (v/v), 10\% ethanol (v/v), 10\% acetone $(\mathrm{v} / \mathrm{v}), 10 \%$ glycerol $(\mathrm{v} / \mathrm{v})$, distilled water, $50 \mathrm{mM} \mathrm{CaCl}_{2}$, $0.1 \mathrm{M}$ acetate buffer $(\mathrm{pH} 4.6), 0.1 \mathrm{M}$ acetate buffer $(\mathrm{pH}$ 5.8 ) and $10 \%$ glycerol prepared in $0.1 \mathrm{M}$ acetate buffer $(\mathrm{pH}$ 4.6) were used for extraction of $\alpha$-amylase enzyme from the viscera. $2 \mathrm{~g}$ sample was ground and mixed with
$50 \mathrm{~mL}$ of different solvents and left for $2 \mathrm{~h}$ at room temperature for soaking. Thereafter, the mixture was centrifuged at $4000 \mathrm{rpm}$ (REMI 8C, India) for $5 \mathrm{~min}$. The clear supernatant was taken as crude enzyme extract.

Different concentrations of solvents mentioned above were used to determine the appropriate concentration for optimum enzyme production. The concentration of solvent so determined was used for the determination of appropriate soaking time using different time periods. The above preparation was set under stationary and agitated $\left(120 \mathrm{U} \mathrm{min}^{-1}\right)$ conditions to observe their effect on leaching of enzymes from the viscera. The effect of temperature on leaching was studied by observing the process at different temperatures i.e., $10-70^{\circ} \mathrm{C}$.

Assay of enzyme activity: The enzyme activity was assayed following the DNS method (Al-Quadan et al., 2009). The absorbance was measured at $560 \mathrm{~nm}$ using a spectrophotometer (Systronics UV-VIS, India).

Isolation and screening of amylolytic bacteria in the viscera: About $10 \mathrm{~g}$ of sample was taken in $90 \mathrm{~mL}$ $0.85 \%(\mathrm{w} / \mathrm{v})$ sterile physiological saline and diluted upto $10^{-4}$ dilution. From the highest dilution $0.1 \mathrm{~mL}$ was taken to inoculate Nutrient agar plate following pour plate method. The isolated pure colony obtained after incubation were preserved in nutrient agar slants under refrigeration at $4^{\circ} \mathrm{C}$ and viability was maintained by sub-culturing. The bacterial isolates were then tested for amylolytic activity using Starch agar method.

Identification of bacterial isolate showing highest amylolytic activity: The bacterial isolate showing highest amylolytic activity was identified on the basis of morphological, cultural and biochemical characteristics as per Bergey's Manual of Determinative Bacteriology.

Solid substrate fermentation: The bacterial isolate showing highest amylolytic activity was used for the production of amylase by solid substrate fermentation on wheat bran. The fermentation was carried out at $37 \pm 1^{\circ} \mathrm{C}$ for 5 days in a $250 \mathrm{~mL}$ Erlenmeyer flask (Ling et al., 2009). The composition of the fermentation media being Wheat bran $40 \%$, Urea $0.2 \%, \mathrm{MgCl}_{2} 1.0 \%$, $\mathrm{KCl} 1.0 \%$ and ribose $4.0 \% .1 \mathrm{~mL}$ of overnight grown culture $\left(2 \times 10^{9}\right.$ cell $\left.\mathrm{mL}^{-1}\right)$ was inoculated on to the sterilized medium. 
Starch recovery from wheat bran: About $15 \mathrm{~g}$ of wheat bran was taken in $100 \mathrm{~mL}$ of distilled water and was boiled for different time periods. $8 \mathrm{~mL}$ of supernatant was taken carefully and $0.5 \mathrm{ml}$ iodine solution was added ( $0.2 \mathrm{~g}$ Iodine in $2 \% \mathrm{KI}$ solution) to it. The absorbance of the supernatant was measured at $610 \mathrm{~nm}$ in a spectrophotometer.

Extraction of crude enzyme post fermentation: About $2 \mathrm{~g}$ of fermented wheat bran was taken and dissolved into $50 \mathrm{ml}$ each of the different solvents i.e., $10 \%$ methanol $(\mathrm{v} / \mathrm{v}), 10 \%$ ethanol $(\mathrm{v} / \mathrm{v}), 10 \%$ glycerol $(\mathrm{v} / \mathrm{v}), 0.1 \mathrm{M}$ of acetate buffer ( $\mathrm{pH} 4.6), 20 \mathrm{mM} \mathrm{CaCl}_{2}$ $(\mathrm{w} / \mathrm{v})$ solution and distilled water; soaked for $1 \mathrm{~h}$ at room temperature, then filtered through cotton cloth and centrifuged at 4000rpm (REMI 8C, India) for 5 min. The supernatant was taken as crude enzyme extract. The unit activity of $\alpha$-amylase of the crude extract obtained from the fermented bran was assayed by following DNS method (Mogentale et al., 2010).

\section{RESULTS}

Physicochemical analysis: The $\mathrm{pH}$ of the viscera was 6.23. The total titrable acidity in the sample was recorded to be 0.675 .

Detection of amylase activity in viscera: A typical zone of clearance was observed around the circular disc after the starch agar plate was flooded with $70 \%$ Logul's iodine solution.

Effect of time on enzyme extraction from the time of fish slaughter: The change in enzyme activity of viscera with the increasing time from the time of slaughter was observed and unit activity of enzyme at different time was recorded (Fig. 3). The highest activity was obtained at $3 \mathrm{~h}$ after slaughtering.

Optimization of different parameters for $\alpha$-amylase extraction from viscera: Among the different solvents studied, $50 \mathrm{mM} \mathrm{CaCl} 2$ was identified to be the best solvent for $\alpha$-amylase extraction from the viscera of $L$. rohita (Ham.) (Table 1). About $20 \mathrm{mM}$ of $\mathrm{CaCl}_{2}$ was the optimum solvent concentration where the maximum

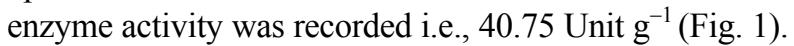
Maximum enzyme activity (47.6 Unit $\mathrm{g}^{-1}$ ) was obtained when the sample to solvent ration was taken as 1:35. Above this concentration the activity slowed down (Table 2). The results showed that 60 min incubation period was the optimum and beyond that no additional effect on amylase extraction was observed (Table 3). Out of the two different leaching conditions used for the study, the agitated condition was found to be better over the stationary condition (Fig. 2). At a temperature of $10^{\circ} \mathrm{C}$ the leaching condition of the enzyme was found to be most effective but at higher temperature the yield was comparatively negligible (Table 4 ).

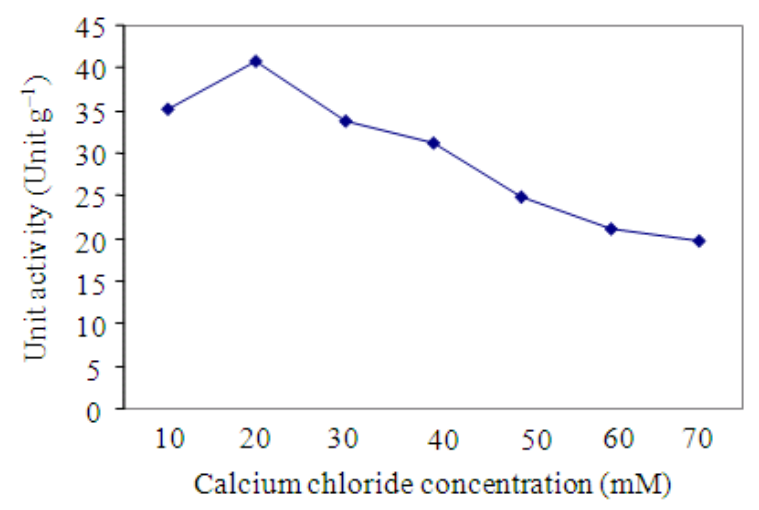

Fig. 1:Effect on amylase activity at different concentrations of $\mathrm{CaCl}_{2}$

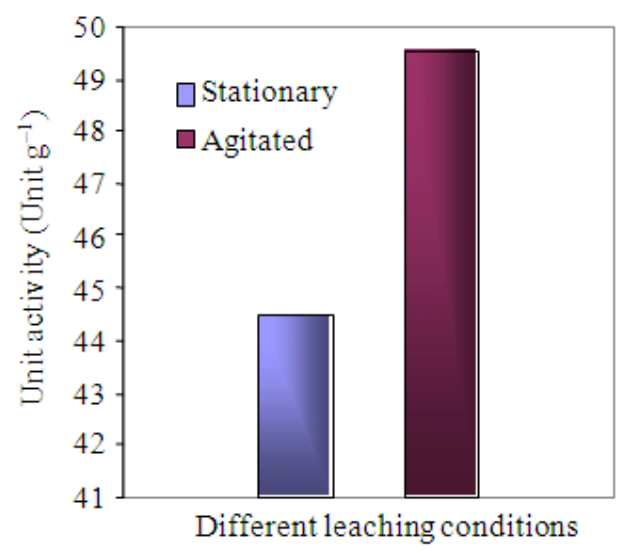

Fig. 2: Effect of physical state on leaching of amylase during extraction

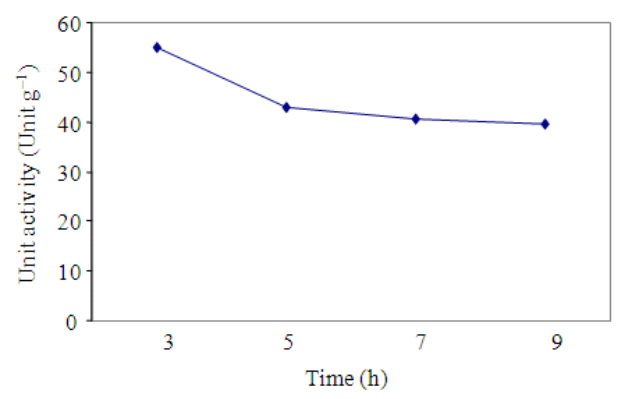

Fig. 3:Activity of Enzyme extracted at different time points post slaughtering of the fish 
Am. J. Microbiology 1 (2): 30-35, 2010

Table 1: $\alpha$-amylase extraction activity in different solvents

\begin{tabular}{lll}
\hline Sl. No. & Solvent $(50 \mathrm{~mL})$ & $\begin{array}{c}\text { Specific activity } \\
\left(\text { Unit }^{-1}\right)\end{array}$ \\
\hline 1 & $10 \%$ Methanol & $16.25 \pm 0.17$ \\
2 & $10 \%$ Ethanol & $13.25 \pm 0.03$ \\
3 & $10 \%$ acetone & $15.73 \pm 0.07$ \\
4 & $10 \%$ Glycerol & $17.62 \pm 0.01$ \\
5 & Distilled water & $18.11 \pm 0.01$ \\
6 & $50 \mathrm{mM} \mathrm{CaCl}_{2}$ & $24.74 \pm 0.53$ \\
7 & Acetate Buffer $(\mathrm{pH} 4.6)$ & $10.23 \pm 0.02$ \\
8 & Acetate Buffer $(\mathrm{pH} \mathrm{5.8)}$ & $12.75 \pm 0.54$ \\
9 & $10 \%$ Glycerol in acetate buffer $(\mathrm{pH} 4.6)$ & $14.85 \pm 0.04$ \\
\hline \multicolumn{2}{l}{ Values are expressed as mean $\pm \mathrm{SD}$, where, $\mathrm{n}=3$}
\end{tabular}

Table 2: Effect of solvent and sample ratio on enzyme extraction

\begin{tabular}{lll} 
S1. No. & Sample: Solvent $(\mathrm{g}: \mathrm{mL})$ & $\begin{array}{c}\text { Specific activity } \\
\left(\mathrm{Unit}^{-1}\right)\end{array}$ \\
\hline 1 & $1: 10$ & $16.0 \pm 0.81$ \\
2 & $1: 15$ & $25.8 \pm 0.07$ \\
3 & $1: 20$ & $32.4 \pm 0.14$ \\
4 & $1: 25$ & $36.0 \pm 0.81$ \\
5 & $1: 30$ & $40.8 \pm 0.85$ \\
6 & $1: 35$ & $47.6 \pm 0.21$ \\
7 & $1: 40$ & $42.8 \pm 0.86$ \\
\hline \multicolumn{2}{l}{ Values are expressed as mean \pm SD, where, $\mathrm{n}=3$}
\end{tabular}

Table 3: Effect of incubation time on enzyme activity

\begin{tabular}{|c|c|c|}
\hline Sl. No. & Incubation time (min) & $\begin{array}{l}\text { Specific activity } \\
\left(\text { Unit }^{-1}\right)\end{array}$ \\
\hline 1 & 30 & $49.00 \pm 0.40$ \\
\hline 2 & 60 & $56.70 \pm 1.11$ \\
\hline 3 & 90 & $52.80 \pm 0.90$ \\
\hline 4 & 120 & $39.90 \pm 0.60$ \\
\hline 5 & 150 & $36.75 \pm 0.32$ \\
\hline 6 & 180 & $29.40 \pm 0.43$ \\
\hline 7 & 210 & $26.60 \pm 0.86$ \\
\hline \multicolumn{3}{|c|}{ Values are expressed as mean $\pm \mathrm{SD}$, where, $\mathrm{n}=3$} \\
\hline \multicolumn{3}{|c|}{ Table 4: Effect of temperature on leaching process } \\
\hline Sl. No. & Temperature $\left({ }^{\circ} \mathrm{C}\right)$ & $\begin{array}{l}\text { Specific activity } \\
\left(\text { Unit }^{-1}\right)\end{array}$ \\
\hline 1 & 10 & $60.20 \pm 0.13$ \\
\hline 2 & 20 & $58.45 \pm 0.41$ \\
\hline 3 & 30 & $57.40 \pm 0.43$ \\
\hline 4 & 40 & $55.65 \pm 1.27$ \\
\hline 5 & 50 & $22.75 \pm 0.20$ \\
\hline 6 & 60 & $06.65 \pm 0.28$ \\
\hline 7 & 70 & $04.55 \pm 0.36$ \\
\hline
\end{tabular}

Isolation and screening of amylolytic bacteria: A total of fifteen bacterial isolates were obtained from the viscera of $L$. rohita (Ham.) and screened for amylolytic activity on Starch agar plate. Out of 15 isolates tested, NK-7, Bh-4 and Bh-5 shown positive result for amylase production. Of this, NK-7 exhibited the highest amylase activity with maximum zone of clearance (Fig. 4).

Identification of bacterial isolate (NK-7) showing highest amylolytic activity: Based on the colony characteristic, cultural characteristics, microscopic and biochemical study the bacterial isolate NK -7 was identified as Bacillus megaterium.

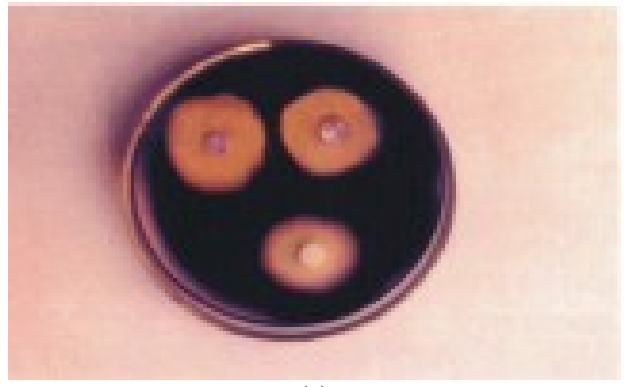

(a)

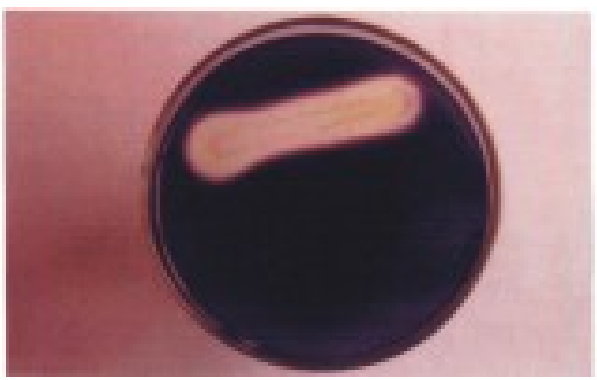

(b)

Fig. 4: (a) Zone of clearance shown by three bacterial isolates from Viscera of L. rohita (Ham.); (b) Zone of clearance shown by isolate NK-7

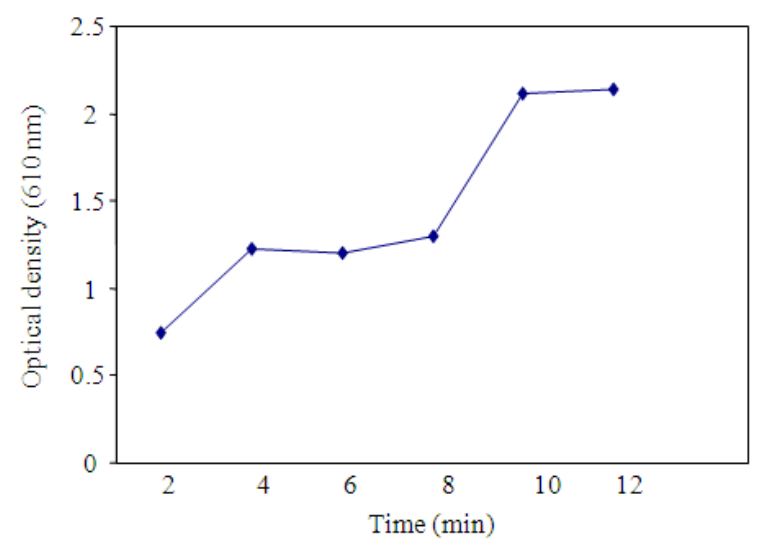

Fig. 5: Starch-iodine complex at different boiling point

Starch recovery from the wheat bran: The absorbance values of starch-iodine complex at different time increased gradually that representd the higher amount of starch recovery from the wheat bran with increasing boiling time (Fig. 5).

a-amylase production in fermented wheat bran using different solvents: Among the different solvents, $10 \%$ ethanol was found to be the best (Fig. 6). The

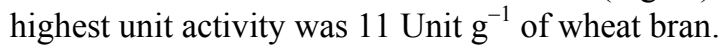


Am. J. Microbiology 1 (2): 30-35, 2010

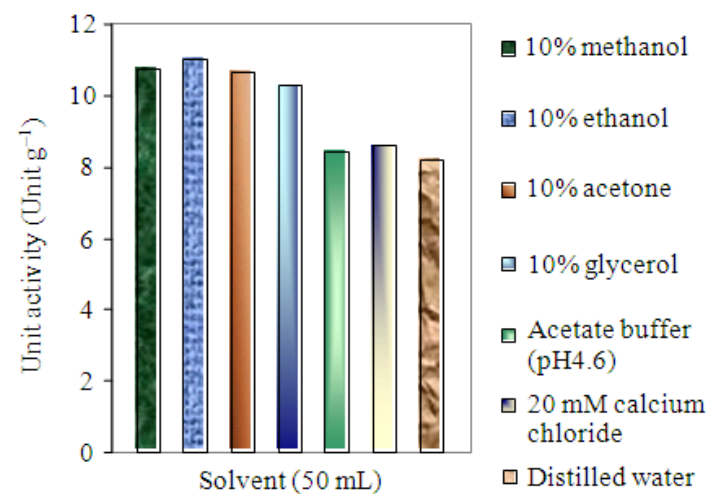

Fig. 6: Enzyme activity in presence of different solvents obtained from fermented wheat bran

\section{DISCUSSION}

The main objective of this study was the efficient extraction of $\alpha$-amylase from an easily available source at minimum cost. Viscera of Labeo rohita (Ham.), which is a waste and easily available, was selected. The present study also aimed at solving the problem of environmental pollution caused due to improper disposal of fish viscera. We first tried the detection of amylase enzyme from the viscera and then attempted to optimize different parameters for extraction of enzyme from the sample.

The extraction efficiency of the solvent is critical to the recovery of enzyme from any source; hence selection of the suitable solvent is necessary. Different solvents were tried for extraction of amylase from viscera. $\mathrm{CaCl}_{2}$ solution was the best solvent (Table 1). Depending upon the dielectric constant of the solvent the molecules are extracted. Organic solvents possess lower dielectric constant than the inorganic solvents. Generally, amylase is extracted in organic solvents (Petrus et al., 2009) such as ethanol, methanol, glycerol. But during our investigation, $\mathrm{CaCl}_{2}$ acted as the best solvent that might be attributed to some stimulatory effect of $\mathrm{CaCl}_{2}$ on amylase extraction and activity. A range of concentrations i.e., 10-70 mM of $\mathrm{CaCl}_{2}$ was tried for extraction of amylase. $20 \mathrm{mM}$ concentration gave the best result (Fig. 1). This may be due to the fact that $\alpha$-amylase is a metaloenzyme, which binds on $\mathrm{Ca}^{2+}$ with high affinity at a specific site. Chloride ion $\left(\mathrm{Cl}^{-}\right)$activation has been demonstrated in mammalian and salivary $\alpha$-amylase and structurally related bacterial enzyme from Alteromonas halophantis whereas most microbial $\alpha$-amylase are reported to be chloride independent. Excess of $\mathrm{Ca}^{2+}$ results in binding of a second $\mathrm{Ca}^{2+}$ at the active site and inhibit enzyme activity (Mogentale et al., 2010). In this native state, the enzyme molecules of $\alpha$-amylase remain inside the cells along with other components. Thus adequate amount of solvent is required to leach out the enzyme present inside the cell. Activity of amylase was highest (47.6 Unit $\mathrm{g}^{-1}$ ) at 1:35 solvent: sample ratio (Table 2). This suggests the optimum ratio, which allows efficient binding of $\mathrm{Ca}^{2+}$ to the $\alpha$-amylase molecules. The optimum time for total binding of $\mathrm{Ca}^{2+}$ to the enzyme present in viscera was also determined. Sixty minutes incubation period was optimum (Table 3) within which $\mathrm{Ca}^{2+}$ bound to the enzyme optimally. Amylase activity decreased beyond this, indicating inhibition of $\alpha$ amylase activity due to degradation of indigenous amylases by bacteria developing in the ground viscera. Activity was maximum at $10^{\circ} \mathrm{C}$ (Table 4). This may be because lower temperatures slow down bacterial growth. Out of two physical states studied for leaching of enzyme, the agitated condition was observed to be better over the stationary condition. It is because upon agitation the ground viscera get distributed uniformly in the continuous phase of solvent, reducing concentration polarization (Al-Taweil et al., 2009). Biocatalysts can function efficiently only at their optimum temperatures. The effect of temperatures on leaching process has been studied at different temperatures points ranging from $10-70^{\circ} \mathrm{C}$ keeping all other parameters at optimum conditions. In the present investigation, $10^{\circ} \mathrm{C}$ was the optimum temperature for leaching of the enzyme (Fig. 2 ), at higher temperature the yield was less. This might be due to the denaturation of enzyme at high temperatures.

The alimentary canal of the fish harbours microbial flora. So, the possible amylolytic activity of bacterial flora present in the alimentary canal was studied by isolating and screening the bacteria having amylolytic activity. Out of the 15 bacterial isolates, 4 isolates named NK-2, NK-7, Bh-4 and Bh-5 showed amylolytic activity as revealed by Starch agar plate assay (Fig. 4). This indicated the contribution of bacterial amylase in increasing the amylolytic activity of the viscera. The bacterial isolate showing highest enzyme activity was screened at morphological, microscopic and biochemical levels and identified as Bacillus megaterium.

$B$. megaterium showing highest amylolytic activity was allowed to ferment wheat bran (Zaman et al., 2009). There are reports that higher yield of amylase can be obtained in media when complex raw material containing starch from maize, barley, wheat and malt (Nejat et al., 2009) were supplemented. The release of starch granules from wheat bran was indicated by formation of starch-iodine complex upon boiling. In our studies, a greater starch-iodine complex (Fig. 5) indicated increased release of starch from wheat bran. However, 
higher production of amylase in presence of starch by Bacillus licheniformis has earlier been reported (Mubarik et al., 2010; Coulibaly and Chen, 2010).

The $\alpha$-amylase production by $B$. megaterium in solid substrate fermentation on wheat bran was studied using seven different solvents for extraction of enzyme. The highest activity was obtained with $10 \%$ ethanol (Fig. 6). The extraction of the enzyme into the ethanol indicated that organic solvents are more effective than the inorganic one.

The present investigations therefore revealed that the $\alpha$-amylase of the viscera of $L$. rohita (Ham.) is $\mathrm{Ca}^{+}$ dependent metaloenzyme. Since chloride-dependent $\alpha$ amylases are specific to all animals (vertebrates and invertebrates), therefore, the effect of $\mathrm{Cl}^{-}$on the enzyme activity cannot be ignored. Moreover, Further work can be carried out on purification of the crude enzyme obtained from the viscera to be used for commercial application. On the other hand the bacterial enzyme was found to be extracted efficiently in organic solvent i.e., ethanol. The bacterial species $B$. megaterium has been found to be the potent strain for producing $\alpha$-amylase inside viscera of Labeo rohita. Higher yield of the enzyme may be obtained after optimization of other parameters such as nutrient requirements, carbon to nitrogen ratio, $\mathrm{O}_{2}$ supply, temperature control in the fermented broth and during processing.

\section{CONCLUSION}

This finding is case specific as the study was confined to single species of fish of the carp family and therefore, the relevance of other metal ions on probable optimization of enzymes like amylases on other fish community cannot be ignored or denied. Nevertheless, it can be concluded that the present studies confirmed the presence of amylases in rejected fish viscera which can be explored and exploited for human benefit as well as industrial and commercial applications.

\section{REFERENCES}

Al-Quadan, F., H. Akel and R. Natshi, 2009. Characteristics of a novel highly thermostable and extremely thermophilic alkalitolerant amylase from hyperthermophilic bacillus strain HUTBS71. OnLine J. Biol. Sci., 9: 67-74. DOI: 10.3844/ojbsci.2009.67.74

Al-Taweil, H.I., M.B. Osman, A.A. Hamid and W.M.W. Yussof, 2009. Development of microbial inoculants and the impact of soil application on rice seedlings growth. Am. J. Agric. Biol. Sci., 4: 79-82. DOI: 10.3844/ajabssp.2009.79.82
Coulibaly, A. and J. Chen, 2010. Evolution of energetic compounds, antioxidant capacity, some vitamins and minerals, phytase and amylase activity during the germination of foxtail millet. Am. J. Food Technol., 62: 40-51.

Harrison, A.P., R.G. Cooper, M.A. Suliman and U. AlAlami, 2009. The efficacy of karkadeh tea in controlling post-prandial blood glucose levels. Am. J. Pharmacol. Toxicol., 4: 151-157. DOI: 10.3844/ajptsp.2009.151.157

Jarrar, B.M., 2009. Microanatomy and histochemistry of the salt glands of the kentish plover, Charadrius alexandrines (Aves, Charadriidae). OnLine J. Biol. Sci., 9: 75-80. DOI: 10.3844/ojbsci.2009.75.80

Ling, H.S., L.T. Chuan, R. Mohamad and A.B. Ariff, 2009. Characterization of pullulanase Type II from Bacillus cereus H1.5. Am. J.. Biochem. Biotechnol., 5: 170-179. DOI: 10.3844/ajbbsp.2009.170.179

Mehrabadi, M. and A.R. Bandani, 2009. Assessing of $\alpha$-amylase activity of midgut in wheat bug Eurygaster maura. Am. J. Applied Sci., 6: 478483. DOI: 10.3844/ajassp.2009.478.483

Mogentale, S.M., E.J.A. Silva, P.M. Meyer, C.T. Marino and M.C.A. Sucupira et al., 2010. Effects of flavomycin on ruminal fermentation, in situ degradability and in vivo digestibility in bovine fed sugarcane diets. Am. J. Anim. Vet. Sci., 5: 76-85. DOI: 10.3844 ajavsp.2010.76.85

Mubarik, N.R., I. Mahagiani, A. Anindyaputri, S. Santoso and I. Rusmana, 2010. Chitinolytic bacteria isolated from chili rhizosphere: Chitinase characterization and its application as biocontrol for whitefly (Bemisia tabaci Genn.). Am. J. Agric. Biol. Sci., 5: 430-435. DOI: 10.3844/ajabssp.2010.430.435

Nejat, N., $\quad$ K. Sijam, S.N.A. Abdullah, G. Vadamalai and M. Dickinson, 2009. Molecular characterization of a phytoplasma associated with Coconut Yellow Decline (CYD) in Malaysia. Am. J. Applied Sci., 6: 1331-1340. DOI: 10.3844/ajassp.2009.1331.1340

Petrus, A.C., O.H. Ahmed, A.M.N. Muhamad, H.M. Nasir and M. Jiwan et al., 2009. Chemical characteristics of compost and humic acid from sago waste (Metroxylon sagu). Am. J. Applied Sci., 6: 18801884. DOI: 10.3844/ajassp.2009.1880.1884

Zaman, M.Z., A.S. Abdulamir, F.A. Bakar, J. Selamat and J. Bakar, 2009. A review: Microbiological, physicochemical and health impact of high level of biogenic amines in fish sauce. Am. J. Applied Sci., 6: 1199-1211. DOI: 10.3844/ajassp.2009.1199.1211 